\title{
The Impact of Business Strategy Formulation Towards Accountant Role: Star Rating as Moderation Variable in Hotel Industry in Southern Sumatera Region
}

\author{
Antonius Singgih Setiawan ${ }^{\# 1}$, Rahmawati ${ }^{*}$, Djuminah ${ }^{*}$, Ari Kuncara Widagdo* \\ ${ }^{\#}$ Faculty of Economic and Business, \\ Universitas Sebelas Maret and Universitas Katolik Musi Charitas, Indonesia \\ ${ }^{*}$ Faculty of Economic and Business, Universitas Sebelas Maret, Indonesia \\ 1'singgih@ukmc.ac.id
}

\begin{abstract}
This research aims to test and prove the relation of the selection of strategy formulation towards accountant role in hotel business management, and also to test and prove star-hotel rating in moderating the relation between the selection of strategy formulation and accountant role in hotel business management in Southern Sumatera region. This research uses the data which is collected from surveys conducted on star-hotel General Managers (Hotel Leaders) in Southern Sumatera region. 134 questionnaires are given to General Managers (Hotel Leaders). A total of 118 questionnaires (88.06\%) are used in this research. This data is analysed by Moderating Regression Analysis using SPSS software version 21. Findings show that deliberate strategy formulation gives positive impact towards the increase of accountant role in the hotel industry, whereas star rating gives negative interaction effect to deliberate strategy formulation. A new insight of this research is the effort to see interaction effect of star-hotel rating and strategy formulation practice towards accountant role in the hotel industry.
\end{abstract}

Keyword - Deliberate Strategy Formulation, Accountant Role, Star Rating, Southern Sumatera Region

\section{INTRODUCTION}

Sumatera Island is part of Indonesia Republic region. Sumatera Island is located in west part of Indonesia region. Regionally, Sumatera is divided into two big regions, namely Southern Sumatera region, and Northern Sumatera region. These two big regions describe two powerful economic, business, and hospitality industry areas in Sumatera Island. Southern Sumatera region has the center of economy, trade, and hospitality industries in South Sumatera province, precisely in Palembang city. On the other hand, the center of economy, business, and hospitality industries in Northern Sumatera region is in Medan and also Riau Island province that has the center in Batam.

Southern Sumatera region is closed to the government administration, economy, and business in Indonesia that is Java Island. For that reason, Southern Sumatera region is also frequently considered as Java Island's support in the context of economy and business. Southern Sumatera region consists of five provinces; namely Lampung, South Sumatera, Bengkulu, Jambi, and Bangka Belitung. As mentioned previously, South Sumatera becomes the main activator of the economy, business, and hospitality industries activities in this region. South Sumatera province acts as the economic development barometer in Southern Sumatera region. This fact is due to some reasons; many international events have been conducted in South Sumatera province, specifically sports events. 2018 is an important year for South Sumatera province since South Sumatera province will be the host to hold sports multi-events of Asian countries which are known as Asian Games 2018 other than Jakarta.

The growth of economy and business activities will have direct impacts on the hospitality industry growth, specifically hotel industry. Data from Central Bureau of Statistics in the last 5 years (2012-2016) shows that hotel industry in Southern Sumatera region grows in the number of 59.22\%. Hotel industry growth in Southern Sumatera region, specifically in South Sumatera province shows that economy and business activities in this region are increasing. International multi-event activities that are frequently held in this region also trigger the growth increase of hotel industry in this region. Moreover, the growth of hotel industry also has an impact to the increase of positive image of a region. However, it will also increase the competition among hotel managers. This is shown by the number of average hotel occupancy in Southern Sumatera area in the last 5 years (2011 2015 ) of $48.06 \%$. 
Data and description of the hotel industry in Southern Sumatera region show the phenomena of tight competition. This becomes a warning for the businessmen and hotel managers to be able to anticipate and win the competition in the hotel industry. Winning the competition means creating a sustainable operation of hotel business. Because of that, hospitality research and literature grow not only to discuss the strategy choice but also how hotel managers make use of multidisciplinary knowledge to anticipate tight competition in the hotel industry. One of the important science branches to be adopted in the hotel industry is accounting.

Modern hotel business management currently cannot be detached from accounting activity and contribution Collier et al. [1] state that financial function in the hotel industry group is getting more involved in strategic management accounting. The accounting function involvement is not only in the planning but also in estimating market condition and analyzing competitors. This matter explains further that strategic management accounting currently has become an important instrument in the hotel industry. Accountant involvement in an industry is one of the implementations in strategic management accounting, other than the use of sophisticated accounting management technique [2]. Previously, Simon et al. [3] explain the accountant role in a company plays a double role that is various, that is as value protector, and direct the attention to problem-solving.

Hence, the research on strategic management accounting role has grown in many industry sectors, such as the research conducted by Hoque [2], [4-8]. However, those several types of research view the strategic management accounting concept by emphasizing only in strategic management accounting techniques, such as control management system and company performance measurement system. The implementation of strategic management accounting research that is focused on the accountant role in the making company strategic decision is still rarely conducted [2]. On the other side, Gimbert et al. [9] states that the research on the role of potential strategy formulation and implementation of strategy formulation is also still rarely conducted. This situation brings the chance to do more research about the relation of implementation of strategy formulation and the accounting role, especially in the hotel industry.

The increasing growth of management accountant role in hotel industry becomes an interesting focus in the research of hospitality industry. There are several reasons why this research is conducted. First, the accountant has a bigger role in the strategic management process [10]. Second, the important role of management accountant is to help give information to make a decision and strategic control [11]. Those two things are really relevant to hotel industry needs to win the competition. However, the next question is what triggers the effectiveness of a hotel company to make use of the accountant role in managing hotel operation. Several literature reviews have identified that the strategy formulation decision determination is predicted to be an important factor in optimizing accountant role in a company [2], [11].

In other words, star rating will show the certification level that can reflect the ownership of information technology that is more sufficient to support performance creation in the hotel industry [12]. The higher qualification of hotel certification will give impact to the management implementation [13], where accountant has a big role nowadays in hotel industry management and is predicted to have a positive impact on the hotel performance at the end. In other words, star rating that reflects hotel management quality level can support effective strategy formulation process on one side and the increase of optimum role of accounting function in another side in the hotel industry.

Based on the analysis above, it is clear that the rapid number of industry growth will result to more tight competition. Data shows the reality that the average of hotel occupancy level in Southern Sumatera region is still low. Anticipation to face the competition becomes very important to be conducted by hotel industry managers. The utilization of accountant role in supporting the production of strategic information for management needs to be optimized. For this, the first important focus that will be done in this research is to observe how high the accountant role in the hotel industry in Southern Sumatera region contributes to produce a strategic decision for hotel management. Eventually, this research aims to test and prove the impact of the selection of strategy formulation towards accountant role in hotel business management, and also to test and prove star-hotel rating in moderating the relation between strategy formulation and accountant role in managing hotel business in Southern Sumatera region

\section{METHOD}

\section{A. The Impact of Strategy Formulation Towards Accountant Role}

Cadez et al. [2] explain that the choice of strategic actions such as strategy choice and strategy formulation have an important role in implementing strategic management accounting. Gimbert et al. [9] state that strategy formulation is a process where a company defines the long-term direction in overall and defines company scope. Deliberate strategy formulation is a strategy that is planned carefully and controlled by the organization. Deliberate strategy formulation starts with an idea, a plan that is developed further, then that plan is communicated, and ended with several forms of action [14]. 
Mintzberg et al. [15] state that there are three conditions describing that a strategy is formulated intentionally. First, there must be precise intention in the organization, articulated in the level that is concrete and detail so that there is no doubt about what is wanted before taking action. Second, the action has collective quality. This can be done to eliminate doubt possibility related to the absence of organization intention, generally, almost all, they are the subject. Third, the collective intention must have been realized as what is desired, meaning that there is no external power (market, technology, politics, and others) that can disturb.

Deliberate strategy formulation describes a conscious action implying that an organization often discusses strategy to achieve company effectiveness that involves all functional areas, including strategic accounting involvement [11]. This underlies Cadez et al. [2] assumption that strategy formulation orientation that is more intentional produces more accounting participation in the strategic decision-making process. Another assumption is that strategic management philosophy that is intentional will show bigger choice in strategic information orientation such as provided by strategic management accounting.

That shows deliberate strategy formulation is believed to be able to give positive impact towards strategic management accounting. The argumentation has been conducted by Cadez et al. [2] concluding that deliberate strategy formulation gives positive impact towards accountant participation in the process of making a strategic decision. A strategic accountant is an integral part of the process of making a strategic decision [16]. Based on that case, the hypothesis that is shown in this research is:

H1: The accountant role in the strategic decision-making process will be bigger in the company that takes deliberate strategy formulation approach.

\section{B. Star Rating Moderates the Relation of Strategy Formulation Towards Accountant Role}

Lamminmaki [17] confirms that hospitality company level seen based on the star rating is as hotel quality standard. Hotel type is a strategic and important variable that is directly related to the hotel facility service, operation, and market segment target, that in turn produces different hotel performance level [18]. Cser et al. [19] explain that hotel rating term, hotel gradation, hotel classification or hotel segment is used to show hotel differences seen from price, service, and facility that are provided. That also gives impact to the management process that is done by hotel management.

Rhee et al. [20] state the importance of value for hotel groups that have higher star classification tends to be greater than hotel groups that have lower star classification. The impact is a hotel with high star classification will be better in managing strategy than a hotel with low star classification. Another impact is a hotel with high star classification will optimize accounting role than hotel groups with low star classification. This is explained by Lamminmaki [17] that hotel quality that is based on the star rating gives positive impact towards sophistication role of accounting.

Tari et al. [12] conclude that hotel quality that is shown with certification has better performance than a hotel without certification. Good performance shows that hotel has conducted proper and effective strategy formulation so that it can support optimum performance achievement. Zhang et al. [21] find conclusion that management quality aspect can influence performance. Management quality can reflect how coordination among parts in an organization runs effectively including company accounting function role.

Based on the description, it can be seen that the higher star-hotel rating will reflect higher quality; therefore, company needs better accountant role support in order to increase hotel performance. Hence, quality becomes an important key to improve accounting role in the hotel industry. On the other side, hotel quality must be supported with effective strategic plan formulation ability. Deliberate strategy formulation becomes an important key to reflect the quality of hotel business operation. Based on those two things, it can be understood that hotel quality based on star rating can support effective strategy formulation implementation in one side and hotel quality based on hotel rating can support the implementation of accountant role that is more optimum in another side. Therefore, this research hypothesis is:

H2: Star-hotel rating moderate's positive relation of deliberate strategy formulation towards accountant role in the hotel industry.

\section{Samples}

The samples in this research is star-hotel management (general manager) in Southern Sumatera region. This research uses the type of primary data. Data are collected using survey techniques by giving questionnaires as a research instrument directly to the research respondents General Manager (the head of the hotel business) hotel affairs in Southern Sumatera region. Survey was done in 134 hotels in Southern Sumatera region, 12 hotels refuse to be surveyed with various reasons. 4 hotels did not give complete data in accordance with research needs. Hence, based on those 118 questionnaires, this research was conducted. Seen from gender side, the leaders that are involved in the research are men in the number of 87 people (73.7\%), while women respondents are in the number of 31 people $(26.3 \%)$. This shows that men's role is still dominant in management and decision making in business organization particularly in the hospitality business in Southern Sumatera region. 
The respondent profile is seen from the highest education level. Diploma education dominates the last education level from respondents that occupy in a management position in the number of 59 people $(50 \%)$. Undergraduate degree (S1) level in the number of 55 people (66.6\%), the rest is Senior High School level in the number of 4 people (3.4\%). Respondent profiles based on age can be seen that respondent age average is 39,4 years old at the youngest age is 22 years old and the oldest age is 65 years old. If it is seen from the length of position occupation, an average of respondents that are involved in hotel management has occupied for 5 years, while the shortest period of occupation is 1 year and the longest period of occupation is 30 years.

\section{RESULT AND DISCUSSION}

\section{A. Measurement}

Accountant role is an accountant's active role in contributing to produce company strategic decision. Accountant participation measurement used an instrument that was used by Cadez et al. [2] that was adopted from Wooldrige et al. [22]. Respondents were asked to record accountant participation related to five strategic management aspects, namely (1) identifying the problem and suggesting a goal, (2) producing choices, (3) evaluating choices, (4) developing choices in detail, and (5) taking action that is needed for company change. The answer uses 6 point scale $(1=$ have no role at all, $6=$ have full role $)$.

Deliberate Strategy Formulation is to assess how far the organization makes intentional strategy formulation orientation [2]. The instrument is developed based on Mintzberg 's terminology [15]. Respondents were asked to show agreement level with 6 Likert scale $(1=$ strongly disagree until $6=$ strongly agree $)$, with statements namely: (1) in company, strategic decision maker usually thinks further through everything that relates to strategic action, (2) in company, strategic intention is sometimes done with a few or without deviation and (3) in company, strategic action usually grows not apart from intention. Star rating is seen from hotel rating (star-hotel level). The measurement uses Lamminmaki's instrument [17] with scale 1 for 1 -star hotel until 5 for 5 -starhotel.

\section{B. Data Analysis}

Accountant role data in hotel management activity in Southern Sumatera region shows the average of 23.66. Based on theoretical range from 5 to 30 , it can be concluded that accountant role in hotel management activity in Southern Sumatera region can be classified in high level relatively. Deliberate Strategy Formulation Data shows the average number of 14.49 based on the strategy formulation theoretical range from 3 to 18 . This can be concluded that the average number of hospitality company in Southern Sumatera region has relatively high deliberate strategy formulation practice. In terms of star rating profile, hotel with 2 star qualification has more number which is 38 hotels (32.2\%), 3star qualification in the number of 34 hotels (28.8\%), 1 star hotel qualification in the number of 27 hotels $(22.9 \%)$, while hotel with 4 star qualification in the number of 17 hotels (14.4\%), and hotel with 5 star qualification in the number of 2 hotels (1.7\%).

Table I shows the result of research data validity. Validity test is based on the corrected item-total correlation value (r-value). Based on the number of sample of 118 , then the $r$ critical value criteria are exactly in the degree of freedom n: $118-2=116$, in $\alpha 5 \%$ two tail that shows number 0.1809 . Therefore, all variable indicators of strategy formulation and accountant role are stated valid. This can be proved that all $\mathrm{r}$ statistic value from each variable indicator has a greater number than $r$ table value 0.1809 .

Table 1 shows the result of data reliability test. The test result of Crombach Alpha shows that all variables are tested, including Strategy formulation and accountant role variables show that the number above is a critical value that is recommended $(0.8)$.

TABLE I. The Result of Data Validity Test

\begin{tabular}{|c|c|c|}
\hline Research Variables & Validity & Cronbach Alpha \\
\hline \multicolumn{3}{|l|}{ Strategy Formulation } \\
\hline $\begin{array}{l}\text { The strategic decision making by considering the } \\
\text { strategic development }\end{array}$ & 0.886 & \multirow[t]{3}{*}{0.931} \\
\hline Strategic intention can be realized without deviation & 0.801 & \\
\hline The strategic action develops based on the intention & 0.894 & \\
\hline \multicolumn{3}{|l|}{ Accountant Role } \\
\hline Identifying problems and proposing objectives & 0.902 & \multirow[t]{5}{*}{0.983} \\
\hline Generating options & 0.965 & \\
\hline Evaluating options & 0.963 & \\
\hline Developing details about options & 0.960 & \\
\hline Taking the necessary actions to put changes into place & 0.958 & \\
\hline
\end{tabular}


TABLE III. Regression

\begin{tabular}{|l|c|c|}
\hline \multicolumn{1}{|c|}{ Variable } & $\boldsymbol{\beta}$ & \multicolumn{1}{c|}{ t statistic } \\
\hline Intercept & -1.938 & $-0.426(0.671)$ \\
\hline Strategy Formulation & 1.569 & $5.108(0.000)^{* * *}$ \\
\hline Star Rating & 5.889 & $3.017(0.003)^{* * *}$ \\
\hline Strategy Formulation*Star Rating & -0.317 & $-2.497(0.014)^{* *}$ \\
\hline F Test & & $23.835(000)^{* * *}$ \\
\hline $\mathbf{R}^{2} \mathbf{0 . 3 8 5}$ & & \\
\hline Adjusted $\mathbf{R}^{2} \mathbf{0 . 3 6 9}$ & & \\
\hline
\end{tabular}

$* * *$ significant at $1 \%$
$* * \quad$ significant at $5 \%$

Table II shows that regression test result of the influence of strategy formulation towards accountant role and star rating moderates the relation of strategy formulation towards accountant role. Regression test result shows that coefficient value $\beta$ of strategy formulation is significant (1.569) in significance level 1\%. This finding successfully confirms H1 that states accountant role in strategic decision making will be bigger in the company that takes deliberate strategy formulation approach. Regression test result also shows star rating gives positive impact towards accountant role in the hotel industry in Southern Sumatera region. This is shown with coefficient value $\beta$ of star-rating in the number of significant 5.889 in significance level $1 \%$. Interaction test result between strategy formulation and star rating gives impact towards accountant role in the hotel industry in Southern Sumatera region in coefficient value $\beta$ of significant -0.317 in significance level $5 \%$. However, unsuccessful finding confirms $\mathrm{H} 2$ that shows star-hotel rating moderates positive relation of deliberate strategy formulation towards accountant role in the hotel industry.

\section{Discussion}

Based on the hypothesis test in the previous part, accountant role in company strategic decision making is highly influenced by deliberate strategy formulation choice by the company in the hotel industry in Southern Sumatera region. The finding supports Cadez et al. [2] who state that deliberate strategy formulation orientation will be bigger in producing accountant participation in strategic decision-making process. This is very reasonable since deliberate strategy formulation describes a strategy formulation that is started with deep identification process of various problems that happened in the past time that further needs to be a strategic decision for the company. In this situation, the accountant has a strategic role in running every action that is needed.

That reason is in line with Bromwich's view [11] that deliberate strategy formulation describes a conscious action that is implemented by an organization with frequently conducting discussion activity related to the strategy to achieve company effectiveness. This discussion activity will be conducted by involving all functional areas, including involving strategic accountant more intensively. Therefore, this finding becomes the reason that the higher implementation of deliberate strategy formulation, the higher accountant role in contributing in making a strategic decision for company.

Although this research fails to support the second hypothesis, yet this research result shows that star rating can give direct impact towards the increase of accountant role in the hotel industry in South Sumatera region. This research finding shows result anomaly. The research finding shows that star rating gives negative interaction effect of deliberate strategy formulation and accountant role. This gives the meaning that the higher star rating gives no more impulse of the influence of deliberate strategy formulation towards accountant role, while the lower star rating precisely gives higher impulse of deliberate strategy formulation towards accountant role in the hotel industry in South Sumatera region.

This second finding is not in line with hypothesis assuming that the higher star rating will drive the influence of deliberate strategy formulation towards accountant role. The assumption that possibly explains this finding is naturally hotel that has high rating; the accountant role has been high; while deliberate strategy formulation activity has become fundamental needs. On the other side, a hotel that has lower star rating tries to overtake the higher star-rating hotel because they have fallen behind from higher star-rating hotel. This gives impact to their efforts to increase more deliberate strategy formulation and the increase of accountant role in their business operation. However, as explained previously, star rating gives direct positive impact to the accountant role in the hotel industry in Southern Sumatera region. Complex service quality and facility supply in the hotel industry will relate to the cost allocation that is not small as company investment. Therefore, accountant role is highly needed. This supports the findings of Tari et al. [12] and Kim et al. [18] that state the higher hotel star-rating, the more sophisticated accounting activity they run. That will give more positive impact towards accountant role in the hotel industry. 


\section{CONCLusion}

Deliberate strategy formulation gives impact towards accountant role in making a strategic decision. This finding shows that the stronger deliberate strategy formulation becomes the choice in strategic planning of hospitality industry in South Sumatera region, then it will support the accountant role stronger to involve in making company strategic decision. The choice of deliberate strategy formulation and accountant role in making a strategic decision for hotel company cannot be avoided. Hotel industry competition that is more dynamic demands serious attention from each of hotel manager to implement the choice of deliberate strategy formulation and to increase accountant role in making strategic decision to maintain hotel continuance that they manage.

Star rating becomes a serious point to be noticed. The higher star-rating, then the service demand and hotel facility that is expected by customers will also higher. This situation also needs to get serious attention in formulating strategic planning and controlling success from that strategic activity implementation. The accountant has a high important role to ensure hotel service quality for customers. The complexity owned by high star-rating hotels needs effective control and management, accounting function will have a higher role in the situation like this. Hence, it has a base that the higher star-rating, then the need for accountant participation in making a strategic decision is also higher.

This research finding gives several important implications that become the consideration for hotel industry managers. This finding has shown that accountant role is really important in company business strategy management. The choice of strategy formulation becomes an important key to accountant role increase. An important implication of this research result for hotel industry manager is that the involvement of accounting function role is important and deliberate strategy formulation is the most appropriate choice to plan a competitive strategy for the hotel business. The high hotel star-rating that is managed will give impact to the customer demand of expected service quality and luxury facility that are expected. Therefore, accountant role in implementing strategy formulation and ensuring company strategic decision can be run higher.

The fundamental limitation of this research is research generalization matter. This research is only conducted in Southern Sumatera region with hotel industry characteristics that give more service for businessmen and transit guests. Southern Sumatera region is not characterized as a tourism region. Recommended further research can expand research area by considering similar hotel business characteristics. This research fails to prove positive moderation effect of star-rating in the relation of deliberate strategy formulation towards accountant role in the hotel industry. Further research is suggested to view other contextual factors, such as network groups, hotel environment or local culture hotel characteristics.

\section{REFERENCES}

[1] P. Collier P. and A. Gregory, "Strategic management accounting", International Journal of Contemporary Hospitality Management, vol. 7 , no. 1, pp. $16-21,1995$.

[2] S. Cadez and C. Guilding, "An exploratory investigation of an integrated contingency model of strategic management accounting", Accounting Organizations and Society, vol. 33, pp. 836 - 8637, 2008.

[3] H.A. Simon, G. Kozmetsky, H. Guetzkow, and G. Tyndall, "Organizing for controllership: centralization and decentralization", The Controller Copyright Financial Executives Institute, vol. 33, pp. 11 - 18, 1955.

[4] Z. Hoque, "A Contingency model of the association between strategy, environmental uncertainty and performance measurement: Impact on organizational performance", International Business Review, vol. 13, no. 4, pp. $485-502,2004$.

[5] X.S.Y. Spencer, T.A. Joiner, and S. Salmon, S., Differentiation strategy, performance measurement system and organizational performance: Evidence from Australia", International Journal of Business, vol. 14, no. 1, pp. 83 - 103, 2009.

[6] D.M. Fleming, W.C. Chow, and G. Chen, G., "Strategy, performance measurement systems, and performance: A study of Chinese firms", The International Journal of Accounting, vol. 44, no. 3, pp. 256 - 278, 2009.

[7] E. Bastian, and M. Muchlish, "Perceived environment uncertainty, business strategy, performance measurement system and organizational performance", Procedia - Social and Behavioral Sciences, vol. 65, pp. 787 - 792, 2012.

[8] M.S. Macinati, and E.A. Pessina, "Management accounting use and financial performance in public health-care Organisations: Evidence from the Italian national health service", Health Policy, vol. 117, pp, 98 - 111, 2014.

[9] X. Gimbert, J. Bisbe, and X. Mendoza, "The role of performance measurement systems in strategy formulation processes", Long Range Planning, vol. 43, pp. 477 - 497, 2010.

[10] R. J. Palmer, "Strategic goals and objectives and the design of strategic management accounting systems", Advances in Management Accounting, vol. 1, pp. $179-204,1992$.

[11] M. Bromwich, Strategic management accounting in management accounting handbook. Drury. C. (Ed) The Chartered Institute of Management Accountants, 1996.

[12] J. J. Tari, E. Cortes, C. Jorge, P.M. Jose, and F.M. Azorin, "Is it worthwhile to be a quality certified hotel? Evidence from Spain", International Journal of Quality \& Reliability Management, vol. 26, no. 9, pp. 850-864, 2009.

[13] E. Claver, J. J. Tari, and J. Pereira, "Does quality impact on hotel performance?", International Journal of Contemporary Hospitality Management, vol. 18 , no. 4 , pp. $350-358,2006$.

[14] O. C. Bozkut, and A. Kalkan, "Strategic focus in Turkish SMEs: Emergent or deliberate strategies?", Procedia - Social and Behavioral Sciences, vol. 99, pp. $929-937,2013$.

[15] H. Mintzberg, and J. A. Waters, "Of strategies deliberate and emergent", Strategic Management Journal, vol. 6 no. 3, pp. 257 - 272, 1985.

[16] T. W. Scott, and P. Tiessen, "Performance measurement and managerial teams", Accounting Organizations and Society, vol. 24, pp. $263-285,1999$. 
[17] Lamminmaki, D. 2008. Accounting and the management of outsourcing: An empirical study in the hotel industry. Management Accounting Research. Vol 19 (2). pp. $163-181$

[18] K. Cser, and A. Ohuchi, "World practices of hotel classification systems", Asia Pacific Journal of Tourism Research, vol. 13 no. 4, pp. $379-398,2008$.

[19] W. G. Kim, M. Cho, and R. A. Brymer, Determinants affecting comprehensive property-level hotel performance: The moderating role of hotel type", International Journal of Hospitality Management, vol. 34, pp. 404- 412, 2013.

[20] H. T. Rhee, and S. B. Yang, "Does hotel attribute importance differ by hotel? Focusing on hotel star-classifications and customers' overall ratings", Computers in Human Behavior, 2015.

[21] D. Zhang, K. Linderman, and G. Schroeder, "The moderating role of contextual factors on quality management practices", Journal of Operations Management, vol. 30, no. 1, pp. 12 -23, 2012.

[22] B. Wooldridge, and S. W. Floyd, "The strategy process, middle management involvement and organizational performance", Strategic Management Journal, vol. 11, no. 3, pp. 231 - 241, 1990. 